\title{
Examining the Significance of General Indian English and Soft Skills: An Employability Perspective
}

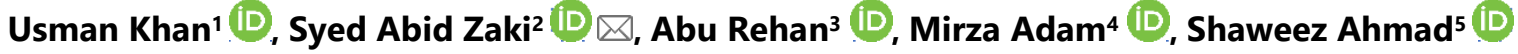 \\ ${ }^{1234}$ Research Scholar, Department of English, Aligarh Muslim University, Aligarh, India \\ ${ }^{5}$ Research Scholar, Department of Social Work, Aligarh Muslim University, Aligarh, India \\ $\triangle$ Corresponding Author: Syed Abid Zaki, E-mail: sabidzaki@gmail.com
}

ARTICLE INFORMATION ABSTRACT

Received: February 19, 2021

Accepted: March 07, 2021

Volume: 3

Issue: 3

DOI: 10.32996/jeltal.2021.3.3.3

\section{KEYWORDS}

General Indian English (G.I.E), intelligibility, soft skills, hard skills, employability.
The Corporate sector has witnessed a drastic change in the last few decades around the world and India is no exception to it. Ever since the proliferation of globalization, inter-state business has grown up like never before. Consequently, multinational companies are gradually taking over the local businesses, which created a paradigm shift in the recruitment processes of companies to meet the demands of the job market. Earlier, people used to get recruited merely on the basis of their job-specific skills called Hard Skills. Today, employers need candidates who can communicate well in English as this language serves as the lingua franca, i.e. a common language of communication among employees of different regional and linguistic backgrounds. Moreover, particular preference is given to the candidates who possess certain necessary skills in addition to hard skills such as communication skill, time management, leadership, adaptability, team work and so on. These skills are known as soft skills. Thus, young job aspirants who can speak fluently and intelligibly in English and possess soft skills get an edge not only during the recruitment process but also during the job. In the above-discussed context, this paper attempts to carry out a critical analysis of teaching General Indian English and soft skills for generating employability among Indian job. To test the same an activity-based study was conducted with a group of 20 undergraduate students which consisted of pre-training and a post-training test. The analysis of the results showed positive changes in students' attitudes and confidence after they undergo soft skills activities as well as spoken English lessons in General Indian English. Thus, this study suggests the integration of a paper on GIE and soft skills across all disciplines at undergraduate level or a short course on the same.

\section{Introduction}

Corporate sector has witnessed a drastic change in the last few decades around the world and India is no exception to it. Multinational companies, today, are gradually taking over the local business because globalization has boosted the inter-state business which in turn has created a paradigm shift in the recruitment processes of companies to meet the demands of the job market. Earlier, people used to get recruited merely on the basis of their job specific skills called as Hard Skills. Today, employers need candidates who can communicate well in English as this language serves as the lingua franca, i.e. a common language of communication among employees of different regional and linguistic backgrounds. Moreover, special preference is given to the candidates who possess certain necessary skills in addition to hard skills such as communication skill, time management, leadership, adaptability, team work and so on. These skills are known as soft skills. Thus, young job aspirants who can speak fluently and intelligibly in English and possess soft skills get an edge not only during the recruitment process but also during the job.

K C AL-KINDI CENTER $\mathbf{R}$ D FOR RESEARCH AND DEVELOPMENT Your gateway to world-class research

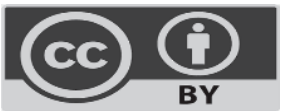

Published by Al-Kindi Center for Research and Development. Copyright (c) the author(s). This open access article is distributed under a Creative Commons Attribution (CC-BY) 4.0 license 
In India every year millions of students get graduated and the numbers get on increasing by each passing year. A recent report of ministry of human resource and development says that the Indian population in higher education grew by 800,000 in the year 2018-19 taking the total number of such students to 37.8 million (Nanda, 2019). However, these ever-increasing numbers do not add to the employability status of the Indian Youth as a large number of graduates are reported to be unemployable. According to India Skills Report, 2020 carried out by Wheebox, only $46.21 \%$ of the total Indian graduates are employable (India skills Report, 2020). The data is more discouraging for the engineering graduates. Job assessment platform Aspiring Minds in its recent annual employability survey revealed that more than $80 \%$ of engineers in India are not fit for jobs as they lack the necessary skills ( $A$ staggering $80 \%$ engineers in India are unemployable, 2020; 80\% engineers not fit for job, says survey, 2019; Over $80 \%$ engineers are unemployable, 2019). The above-mentioned reports regarding the skill-gap among Indian graduates has become one of the most critical concerns of stakeholders and policymakers in the field of education and research. Educational institutions have been struggling to produce graduates who can meet the industry demands (Song \& Tang, 2016). Therefore, to make sure that the students who pass out from colleges and universities are skilled enough to match the skills requirement of the work place in the current scenario they need to be trained with soft skills along with speaking skills in English during their graduation.

\section{Intelligibility in Spoken English}

Intelligibility refers to the speech clarity. It is the technical term for understandability of speech sounds and words. Various forms of spoken English such as American English, British English, Australian English, Indian English, Ugandan English have been originated as a by-product of its global outreach which in turn has created one of the obvious issues among its speakers, i.e. mutual unintelligibility. Gimson (1962) once stated "it is undoubtedly admitted that a good number of foreign learners will need practical purpose for learning English urgently and will perceive no important use in getting the performance of a native speaker and for them information conveying is the main thing" (316). Harmer (2001) too stressed that intelligibility should be considered as the prime goal of pronunciation teaching. Since each variety has an influence of its culture and the regional languages, English sounds different in different regions.

In India, Bengali English sounds different to Kashmiri English which again differs a lot with Tamil English and so on. These regional varieties of spoken English are different from one another in some sounds or the other primarily due to the influence of people's mother tongue or native regional languages. Thus, when people learn English as a second language, they have very strongly formal linguistic habits and these linguistic habits are bound to interfere with their learning English. The following section discusses some examples of differences in the pronunciation of English sounds in regional Indian languages due to the mother tongue influence.

\subsection{Telugu English}

(a) Words have open syllable, i.e. the insertion of vowel at the end of a word. The process of insertion of a sound at the end of word is called paragoge.

- Pen /pen/ > /pennu/

- Light/lait/ > /laitu/

(b) Insertion of /i/ in the beginning of a word.

- Smile /smail/ > /ismailu/

- School /sku:l/> /isku:lu/

2.2 Malayalam English

a) Use of retroflex / $t$ / in place of alveolar / $t$ / (which is unaspirated in the beginning of a stressed syllable).

- $\quad$ Time $/ \mathrm{t}^{\mathrm{h}}$ aim/ $>\quad /$ taim/

- $\quad$ Table $/ \mathrm{t}^{\mathrm{h}}$ eibl/ $>\quad$ teibəl/

(b) Many Malayalam speakers of English replace /t/ with /d/, and /p/ with /b/. Besides, they insert a shwa /ə/ or /i/ in consonant clusters.

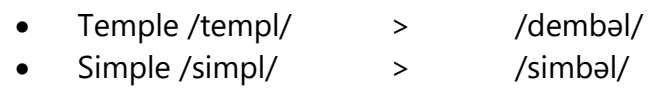

2.3 Assamese English

(a) Assamese speakers of English pronounce /s/ in place of / $/$.They also tend to insert /i/ beginning of a word starting with a /s/ sound. This process is called prothesis.

- Special /spe $\mathrm{fl} \quad>\quad$ /ispesizl/

- Station /steijən/ > /istesən/

(b) Insertion of a shwa / ə / or /i/ in consonant clusters.

- Cream /kri:m/ > /kirim/ 
- Glass /gla:s/ > /gilas/

2.4 Bangla English

(a) $/ \Lambda$ is substituted by / $\mathrm{J} /$

- Club /kl $\wedge \mathrm{b} />\quad / \mathrm{kl} \supset \mathrm{b} /$

- Company /k ^mpəni/ > /kəmpani/

(b) /ei/ becomes /e/

- Survey/səveI/ > /sarbhe/

- Mail/meIl/ > /mel/

(c) $/ \mathrm{f} /$ is realized as $/ \mathrm{p} / \mathrm{or} / \mathrm{ph} /$

- Office /afis/ > /apis/ or /aphis/

- Fifty/frftI/ > /phiptI/

(d) $/ \mathrm{V} /$ is realized as $/ \mathrm{b} /$ or $/ \mathrm{bh} /$

- Fever/fivə/ > /phibha:r/

- Civil/sivil/ > /JIbrl/

2.5 Kashmiri English

(a) Kashmiri speakers of English find it difficult to pronounce words with consonant clusters as they do not have many. Thus, they insert /i/ or / $\partial$ / in consonant clusters.

$\begin{array}{llll}\text { - } & \text { Skill /skil/ } & > & \text { /sikil/ } \\ \text { - } & \text { School /sku:l/> } & \text { /səku:l/ }\end{array}$

(b) Using /ph/ in place of /f/

- Food /fu:d/ $\quad>\quad / p^{h} u: d$

- Feel /fi:l/ $\quad>\quad / / p^{h i: l /}$

\section{Choice of a Model for Speech Pronunciation}

The gradual emergence of the multiple varieties of spoken English and the above-discussed differences in the pronunciation of English sounds with respect to native English pronunciation has made language teachers, trainers and the policy makers in India choose as to which of these varieties of spoken English should be followed to teach English as second language to the vast population of Indian students. Traditionally, Indian ESL teachers had been following British Received Pronunciation (B.R.P. or R.P.) as the model of speech pronunciation. The present-day version of the accent has been used as the standard in phoneticians' description of the pronunciation of British English for centuries (Roach, 2004). However, ESL trainers and researchers realized that this model of speech is too ideal for Indian learners of English to acquire from their earlier stage of learning English.

Moreover, neither the teacher nor the students' vocal organs are habituated to its use in India, where multiple regional languages are used as native languages. Rather, General Indian English should be made a goal (Husain, 2014) as it serves as the common neutral accent from both communicative and pedagogic points of view to the vast linguistically diverse population of India (Pandey, 1994). GIE is credited to J.B. Harrison and R.K Bansal, Central Institute of English and Foreign Languages, Hyderabad are accredited with GIE for they attempted to present a detailed description of the phonology of Indian English on the basis of information gathered from speakers belonging to different parts of the country and came with this model (Bansal and Harrison 1972, Bansal 1976, 1976-77, 1978, and CIEFL1972). Since G.I.E is devoid of regional peculiarities and inclined more towards acceptability rather than accuracy, it is believed to benefit Indian students across different regions in achieving comfortable intelligibility in speech.

\section{Soft Skills}

Soft skills are the combination of intra personal and interpersonal/social skills, traits or personal attributes like effective communication, time management, team work, resilience, adaptability, professionalism etc. that help one's personal, professional, and social lives. Cimatti (2016) defines soft skills as "personal transversal competencies such as social aptitudes, language and communication capability, friendliness and ability of working in team and other personality traits that characterize relationships between people" (p.97). Although, the concept of soft skill is believed to be originated around 1968 and formally appeared in a report on a 1972 CONARC Soft Skills Conference (Wright, 2018), it is only since the last decade or so that this topic came into the spotlight particularly due its colossal value in the corporate world. Today, a bulk of literature can be found 
acknowledging the criticality of soft skills in the corporate world and several major studies have found that these skills are equally and, in some cases, more important than hard skills. To mention a few, the research conducted with Fortune 500 CEOs by the Stanford Research Institute International and the Carnegie Mellon Foundation found that soft skills provide 85\% of our career success, while hard skills provide the other 15\% (Klaus, 2007). Similarly, researches in Boston University, University of Michigan's Ross School of Business stress that workers with soft skills training are $12 \%$ more productive than those without them (Vasanthkumari, 2019). Acknowledging its high impact factor in the workplace, researchers around the globe emphasize that students must be trained with soft skills along with their job-specific or technical skills as they believe these skills are the major competency in nearly all types of professions which complement hard skills and help people in their career advancement (Schulz, 2008; Dixon et.al., 2010; Majid et al., 2012; Cimatti, 2016).

\section{Employability Skills}

International Labour Organization defines employability skills as the skills, knowledge and competencies that enhance a worker's ability to secure and retain a job, progress at work and cope with change, secure another job if he/she so wishes or has been laid off and enter more easily into the labour market at different periods of the life cycle. Individuals are most employable when they have broad-based education and training, basic and portable high-level skills, including teamwork, problem solving, information and communications technology (ICT) and communication and language skills. This combination of skills enables them to adapt to changes in the world of work. Although the term employability has been in prominence since the 1990s, its first publication dates back in 1950s. In the very decade i.e. from 1950s and 1960s employability served a primarily economic purpose, that of achieving full employment (Forrier \& Sels, 2003).

It has been observed that in spite of employment opportunities in India, a large number of students struggle to sale themselves in the job market. This is primarily due to their unemployability. Rao, (2014) elaborates the difference between unemployment and unemployability and says that while unemployment refers to the lack of job opportunities in the job market, unemployability is the dearth of right combination of skills necessary to gain an employment. Since, social development and economic growth of a country is highly dependent on skills and knowledge of its workforce, academicians and industry majors in India need to prioritize the skills enhancement to promote a more inclusive and sustainable growth path.

\section{Incorporating the teaching of GIE and Soft Skills for Employability}

It has been said that unemployability is a bigger issue than unemployment for countries like India. Former president APJ Abdul Kalam Azad once said "It is not unemployment which is a major problem; it is the question of 'unemployability' which is a bigger crisis" (Kalam, 2008). Researchers, academicians and industry majors consider theory-based syllabus, memorization and rote learning, bad career choices, no or few internship programs among the others as the prime factors responsible for the employable status of the Indian youth. As discussed above the training of soft skills and speaking skills in English can prove to be a boon towards enhancing the employability of the youth.

To verify which of the two discussed model of speech i.e. R.P and GIE students comprehend well, a group of 20 students were made to listen to two 5 minute audio clips of conversation carried out in GIE and R.P. separately. Students were asked to note down the conversations of both the spoken forms. The analysis of their written notes revealed that all students comprehended the conversation in GIE better than R.P.

\section{Research Objectives}

1. To analyze the efficacy of soft skills training in stimulating employability among undergraduate students

2. To analyze the efficacy of General Indian English in developing intelligibility in spoken English of the Indian students.

\section{Hypothesis}

H01- Soft skills training contribute towards enhancing the employability

H02- G.I.E helps Indian students achieve speech intelligibility and fluency in English.

\section{Research Questions}

1. Does the soft skills' training stimulate employability among undergraduate students?

2. Is General Indian English effective in developing intelligibility in spoken English?

\section{Research Methodology}

In the present study an attempt was made to study the effect of soft skills training and the GIE on developing employability and intelligibility in spoken English among the undergraduate students of Aligarh Muslim University. The research was designed keeping in mind the objective of the study thus making this study both qualitative and quantitative in nature.

\subsection{Participants and Research Tools}

Twenty undergraduate students of Aligarh Muslim University were the participants of this study. They were made to undergo four different soft skills activities thrice. 


\subsection{Procedure}

Students were made to undergo a set of 4 soft skills' activities targeting some of the soft skills desirable across different job types, thrice, making total 12 sessions of activities. The training ran for 6 days. These activities were divided in two different studies with two activities in each study. Study-1 focused on assessing if General Indian English helps one achieve intelligibility in oral English. Whereas, Study-2 focused on assessing if soft skills activities help one stimulate employability. The performance of the participants in their third round of activities was compared with their performance in the first round.

All the participants and research scholar were wearing masks and sanitized their hands before the activities started. Students were made to sit in the activity hall maintaining social distancing when they were not performing the activities. The overview of the activities is discussed below:

\section{STUDY: 1}

\section{Assessing if General Indian English help one achieve intelligibility in oral English}

ACTIVITY: 1

Listen, Write and Repeat

\section{SKILLS TARGETTED:}

Listening skills, writing skills, speaking Skills in English

\section{STEPS:}

1. An audio of a conversation between two People speaking in British Accent (Received Pronunciation) was played.

2. Students listened to the audio carefully and noted the conversation as fast as possible.

3. The students read the whole conversation they had noted.

4. Now Students were asked to narrate the conversation by themselves in their own words without reading.

5. Another audio of a conversation between two people was played, but this time they were speaking in General Indian English

6. Students repeated the whole activity, i.e. listening to the conversation, writing it and then narrating it in their own words.

ACTIVITY: 2

Just a Minute

SKILLS TARGETTED:

Speaking in coherence and fluency in English

\section{STEPS:}

1. Students were asked to speak for one minute on a random topic like 'My favourite food', 'Social Media' which they were not informed of in advance.

2. They were not allowed to stop in between and or to take long pauses while speaking. For instance;

"Social media is a tool that is becoming quite popular these days because of its user-friendly features. Social media platforms like Facebook, Instagram, Twitter and more are giving people a chance to connect with each other across distances....."

3. Now students were asked to recall and write major points they spoke about the topic. For instance, "it has user-friendly "features, gives people a chance to connect...."

4. Students were made to speak again for one minute on the same topic in which they were asked to repeat the points they had written along with some new ideas. They were asked to write new points they have mentioned in their second speech.

5. The whole process was repeated the third time as the activity continued.

6. The teacher compared their first speech with their third one and tried to find out if they were more fluent in their third speech or not. 


\section{STUDY-2}

\section{Assessing if soft skills activities help one stimulate employability}

ACTIVITY: 1

Attending a Virtual Meeting

SKILLS TARGETTED:

Communication skill in English and Team work

\section{STEPS:}

1. The teacher taught briefly the ethics of attending a meeting.

2. Students were asked to attend a meeting

3. One student hosted the meeting, the other one acted as a team leader while rest of them acted as team members.

4. The team members were asked to provide their opinions on any of the general topics of meetings. For example "how to increase sales of their products?"

5. The students came up with their suggestions after discussing the issue among themselves.

6. The teacher asked the students to write the minutes of the meeting and present them one by one.

\section{ACTIVITY: 2}

Complete the short poem

\section{SKILLS TARGETTED:}

Team Work, Listening Skill, Recalling

\section{STEPS:}

1. Students were divided into two teams.

2. The teacher stood at a good distance from the students.

3. The teacher called the teams one by one and narrated a poem in a low voice so that the other team could not listen to it. For example:

\author{
Once there was a talking fan \\ Electrical his chatter \\ I couldn't quite hear what he said \\ And I hope it doesn't matter \\ Because one day somebody oiled \\ His little whirling motor \\ And all the mystery was spoiled \\ He ran as still as water
}

(Maude Rubin)

4. The teams rushed back to their place and noted down the part of the poem they remembered.

5. The teams came back to the researcher to listen to the poem in alternating turns.

6. The teacher will keep on repeating the poem until any one of the teams complete the poem.

7. The teachers encouraged the teams to complete the poem as early as possible.

8. The same activity was repeated but with a different poem that time. The researcher observed the students individually so as to notice the individual improvement in them.

\section{Results}

All the activities were conducted thrice to observe if soft skills activities can improve the body language, confidence, speech intelligibility and the overall employability of the students. Same activities were conducted in all the three sessions, however their topics (like in case of activity-1 of the study-1, replacing the topic social media with my favourite mode of transport). The assessment was made through marks in obtained by the students in each activity. The researchers compared the performance of the students the first round of activities with the third round. All the students were categorized into three categories after they been marks in each activity, viz. (i) students having no improvement in their performance, (ii) students having slight improvement, and (iii) students having major improvement. This study is purely observation based. The results were written after observing students' performance both in groups and also individually. The following pie charts show the degree of improvement in students after the activities: 
STUDY-1

Assessing if General Indian English help one achieve intelligibility in oral English

\section{Activity-1}

Skills Targeted: Listening, Writing, Speaking

$\square$ No improvement $\square$ Slight improvement $\llbracket$ Major improvement

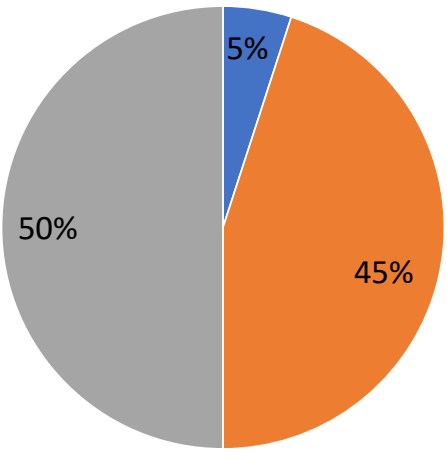

Activity-2

Skills Targeted: Speaking in coherence, fluency in English

$\square$ No improvement $\square$ Slight improvement $\square$ Major improvement

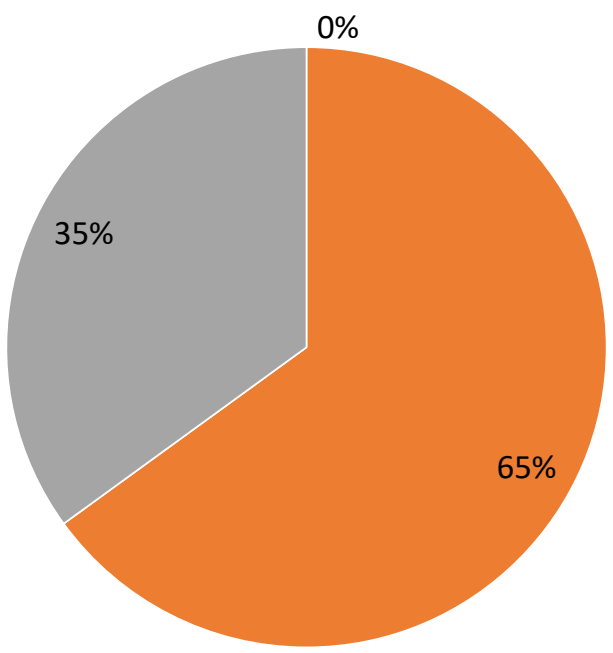


STUDY-2

Assessing if soft skills activities help one stimulate employability

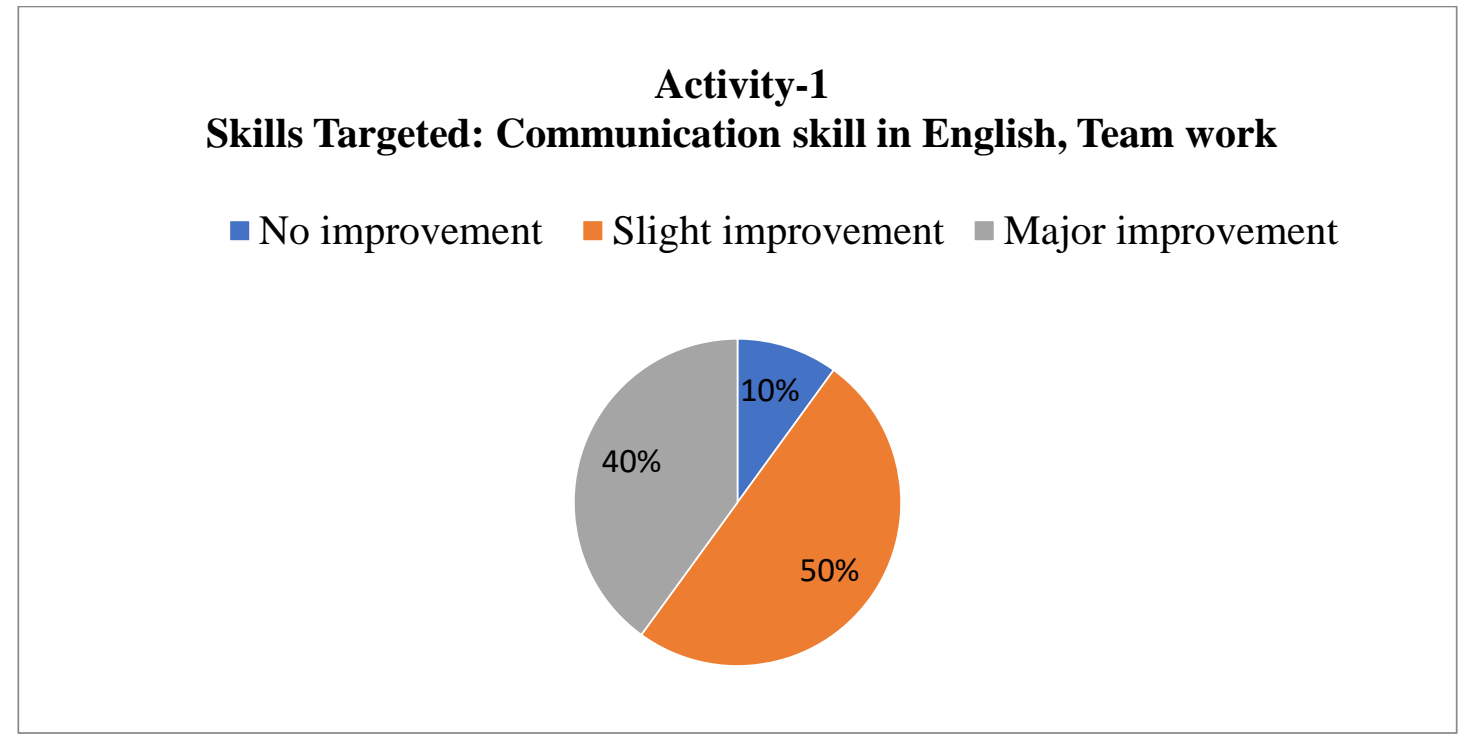

Activity-2

Skills Targeted: Team work, Listening Skill, Recalling

$\varpi$ No improvement $\square$ Slight improvement $\square$ Major improvement

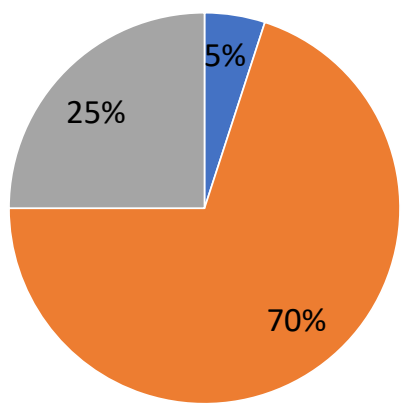

After the completion of all the activities the researcher compared went through their marks in all the three round of activities and found that there was a considerable improvement in students' communication skills in English, team work, work place etiquettes and other skills they were trained with, as their performance in the third round of activities was better than their performance in the first round of activities. Besides, they were also found to have better speech intelligibility in English when following General Indian English as a speech pronunciation model. Thus, on the basis of the results obtained the researcher has accepted both the hypotheses.

\section{Discussion and Conclusion}

The available literature on soft skills emphasises that mere academic abilities alone will not be adequate for them to make themselves employable. It is a bitter truth that most academic institutions are still following theory-based syllabi.

There has not been any practical exercise or internships for the students. Consequently, students and young graduates remain ignorant of the actual work they might do in their professional career and remain unemployable, and possibly unemployed. Thus, what students need is skill-oriented education which is possible with a blend of soft skills and oral skills in English along 
with the theoretic knowledge. The related literature advocates the soft skills training efficiency in enhancing one's soft skills and ultimately the employability. In this context, the researches carried out by Mythili (2013) and Rangnekar (2014) have confirmed that there has been a positive change in attitude and behavior of the subjects after they had undergone the training of soft skills which ultimately enhanced their overall performance. The researchers also suggested that soft skills should be the part of curriculum frame across all educational institutions.

This research paper attempted to test two prime skills significant across different job types, i.e., intelligibility in oral English and employability. Enhanced performance of the students after they had undergone the soft skills activities has confirmed that the soft skills' training is actually helpful in gaining employability skills. Moreover, suppose General Indian English is followed as a model of speech pronunciation for teaching English as a second language to the vast Indian student population. In that case, they will definitely achieve speech intelligibility. Therefore, it is suggested that the teaching of General Indian English and soft skills must be included in the curriculum across all disciplines. Institutions can either include a paper of soft skills and GIE in their syllabi across all disciplines of graduation or a short course of about 3-month course that integrates the teaching of general Indian English with soft skills can be run separately.

Funding: "This research received no external funding".

Conflicts of Interest: "The authors declare no conflict of interest."

\section{References}

[1] A staggering $80 \%$ of engineers in India are unemployable: Report (2020, July 17$)$. Business Insider India. https://www.businessinsider.in/engineers-in-india-lack-the-right-job-skills-including-artificial-intelligence-and-machine-learningreport/articleshow/68516807.cms

[2] $80 \%$ of Indian engineers not fit for jobs, says survey (2019 March, 25). Business Today. https://www.businesstoday.in/current/corporate/indian-engineers-tech-jobs-survey-80-per-cent-of-indian-engineers-not-fit-for-jobs-sayssurvey/story/330869.html

[3] Bansal, R. K., \& Harrison, J. B. (1972). Spoken English. Orient Black Swan.

[4] Bansal, R. K. (1976). The Intelligibility of Indian English. Central Inst. of English and Foreign Languages.

[5] Central Institute of English. (1972). The sound system of Indian English (No. 7). Hyderabad, India.

[6] Dixon, J., Belnap, C., Albrecht, C., \& Lee, K. (2010). The importance of soft skills. Corporate finance review, 14(6), 35.

[7] Forrier, A., \& Sels, L. (2003). The concept employability: A complex mosaic. International journal of human resources development and management, 3(2), 102-124. https://doi.org/10.1504/IJHRDM.2003.002414

[8] Gimson, C. (1962). An Introduction to the Pronunciation of English. Oxford: Oxford University Press.

[9] Harmer, J. (2001). The practice of English language teaching. Harlow: Pearson Longman.

[10] Wheebox (2020) India Skills Report. https://wheebox.com/assets/pdf/ISR Report 2020.pdf

[11] Klaus, P. (2007). The hard truth about soft skills. Harper Collins Publishers.

[12] Majid, S., Liming, Z., Tong, S., \& Raihana, S. (2012). Importance of soft skills for education and career success. International Journal for Cross-Disciplinary Subjects in Education, 2(2), 1037-1042. https://www.researchgate.net/deref/http\%3A\%2F\%2Fdx.doi.org\%2F10.20533\%2Fijcdse.2042.6364.2012.0147

[13] Mythili, T. (2013). An empirical study on the impact of soft skills training given to engineering students of SRM university in Tamil Nadu. (A Doctoral thesis).

[14] Nanda, P.K. (2019). India's Higher Education student population grows by 8 lakh: HRD Ministry. Mint. https://www.livemint.com/education/news/india-s-higher-education-student-population-grows-by-8-lakh-hrd-ministry$\underline{1569081600712 . h t m l}$

[15] Only 47.38\% Indian graduates employable; engineers top the list. (2020). The Indian Express. https://indianexpress.com/article/education/only-47-38-indian-graduates-employable-engineering-tops-the-list-5459556/

[16] Over $80 \%$ Indian engineers are unemployable, lack new-age technology skills: Report. (2019). India Today. https://www.indiatoday.in/education-today/news/story/over-80-indian-engineers-are-unemployable-lack-new-age-technology-skillsreport-1483222-2019-0321\#: : :text=Every\%20year\%2C\%20thousands\%20of\%20engineering,employability\%20assessment\%20company\%20Aspiring\%20Minds.

[17] Pandey, P. K. (1994). On a description of the phonology of Indian English. R. K. Agnihotri et at. Khanna (ed).

[18] Rangnekar, R. (2014). Exploration and impact of soft skills training on performance in academic and non academic organizations. (Doctoral Thesis)

[19] Rubin, M. (N.D). Mystery of the Talking Fan. NCERT

[20] Song, T.K., \& Tang, J. (2016). Managing skills challenges in Asean-5 final report. J.P Morgan

[21] Schulz, B. (2008). The importance of soft skills: Education beyond academic knowledge. Journal of Language and Communication. http://hdl.handle.net/10628/39

[22] Vasanthakumari, S (2019). Soft skills and its application in workplace. World Journal of Advanced Research and Reviews, 3(2),66072.https://www.researchgate.net/deref/http\%3A\%2F\%2Fdx.doi.org\%2F10.30574\%2Fwjarr.2019.3.2.0057 